\title{
Using Moringa oleifera Extracts to Control Blackrot (Xanthomonas campestris) in Field Grown Rape
}

\section{(Brassica napus)}

\author{
Maria Goss ${ }^{1,2}$, Paramu. L. Mafongoya ${ }^{1}$, Augustine Gubba ${ }^{1}$ and Obert Jiri $^{2}$ \\ 1. School of Agricultural, Earth and Environmental Sciences, University of KwaZulu-Natal, Private Bag X01, Scottsville, \\ Pietermaritzburg 3209, South Africa \\ 2. University of Zimbabwe, Faculty of Agriculture, Mt Pleasant, Harare P.O. Box MP167, Zimbabwe
}

\begin{abstract}
The leaf, bark and seed extracts of Moringa oleifera were evaluated for their efficacy under field conditions in suppressing Xanthomonas campestris pv. campestris in rape (Brassica napus. L.). Xanthomonas campestris pv. campestris is an important bacterial pathogen of agricultural importance causing devastating black rot disease of Brassicas. Three extracts concentrations of 60, 100 and $140 \%$ were sprayed as foliar applications weekly and the antibacterial activity was evaluated by recording number of totally defoliated plants. The three extracts showed significant effect against the test pathogen $(p>0.05)$. The antibacterial activity of seed extract demonstrated higher activity against the Xanthomonas campestris pv. campestris as evidenced by lower mean leaf defoliation of 1.59 $\mathrm{cm}$ followed by bark $(2.58 \mathrm{~cm})$ and lastly leaf extracts $(2.96 \mathrm{~cm})(p<0.05)$. There were no significant differences based on the concentration levels used. Observations revealed that $100 \%$ and $140 \%$ levels were not significantly different from each other on enhancing growth of the stem diameter. Moringa seed at $60 \%$ concentration level can be used to enhance growth of rape. The conclusion is that Moringa seed extracts can be effectively implemented to suppress Xanthomonas campestris pv. campestris pathogen in field grown rape in an integrated disease control program.
\end{abstract}

Key words: Xanthomonas campestris pv. campestris, Moringa plant extracts.

\section{Introduction}

Abiotic and biotic factors have a great impact on crop production losses that occur in agricultural systems. The biotic factors affecting agricultural systems include parasitic plants, insects and pathogens. Berger [1] highlighted that losses due to pathogenic diseases can accrue up to $100 \%$ loss on an annual basis, and amongst the devastating pathogens, is the family Xanthomonadacea [2], which is one of the Xanthomonas species that cause tremendous devastating diseases. Xanthomonas campestris is one of the species that has raised great concern among vegetable farmers. Xanthomonas campestris species are plant pathogens ranging from 0.4 to 2.0

Corresponding author: Maria Goss, Ph.D., research fields: agronomy and horticulture. micrometers in size, which exhibit a wide host range [3]. These pathogens are the causal agent of many economically important plant bacterial diseases. The pathogen is aerobic and has been identified as being flagellated, rod shaped, non-spore forming and gram negative [3]. Xanthomonas campestris have been further classified according to their host plants as a source of nutrition. The pathogen Xanthomonas campestris pv. campestris $(X c c)$ causes black rot disease which causes great losses in Brassicas vegetables [3].

Crucifers, which include rape, cauliflower (Brassica oleracea var. botrytis), cabbage (Brassica oleracea var. capitata) and broccoli (Brassica oleracea var. italica) are susceptible to the pathogen causing the bacterial black rot disease [4]. Black rot of crucifers is a cosmopolitan disease that is caused by Xanthomonas 
campestris pv. campestris bacterium [5]. Many Zimbabwean small holder farmers of Brassicas especially Brassica napus, suffer great losses as a result of black rot disease causing up to $100 \%$ losses in vegetables [3]. The seed borne pathogen favors environmental conditions which are warm and humid [2] and these are characteristics of tropical weather found in Zimbabwe. The black rot disease has extensively affected many parts of Zimbabwe with incidence ranging from $10 \%-80 \%$ being experienced in vegetable growing areas [6]. The disease is characterized by V-shaped lesions on the leaf edges which consequently coalesce and may cover the whole leaf area [4]. The affected leaves wilt and have under intense infestations the leaf veins blacken and can devastate the produce even under storage [4]. Heavy infestations on cabbages (Brassica oleracea) by black rot during the early stages of growth prohibit formation of the head which is the plant part of economic importance. There arises therefore, an urgent need to find other sustainable and effective ways to prevent and control Xanthomonas campestris as a way of reducing its devastating effects on vegetable productivity and profitability. Traditionally organic compounds have been in use to counteract disease pathogens and consequently improve yields, quality and unintentionally extend the shelf life of the harvested product [7]. In addition, the cost of production is reduced as the farmers would be using readily available organic resources for the control of pests and diseases [8]. Some important agricultural plant pathogens such as Pythium and Fusarium have been controlled successfully under laboratory experiments through the use of organic compounds [9]. Plant extracts from leaves, seeds and barks that exhibit anti-microbial properties have been commonly used to prevent and control plant bacterial pathogens in the past [7], and some of these prominent extracts have been derived from Moringa oleifera plants. The tree possesses anti-microbial activity, nutritional, therapeutic and prophylactic properties [10] and it has been concluded that Moringa can be successfully utilized as an alternative natural medicine for the prevention and control of bacterial pathogenic diseases [11]. Further studies which were conducted revealed that Moringa leaves have culinary and nutritional properties, whilst the seed extract can be used in the purification of water [10].

Moringa, according to Lant et al. [12], has become an important tree especially in the medical field due to its anti-microbial properties. On the other hand Lurling et al. [13], hypothesized that micro-organisms such as Pseudomonas aureginosa, Staphylococcus aureus, and Escherichia coli, can be effectively controlled by using Moringa extracts. The bacterium E. coli (a gram negative bacterium) is effectively controlled by Moringa extracts [14], therefore there is a high possibility that these extracts can also effectively control Xanthomonas campestris pv campestris as it is also a gram negative bacterium.

Commercial and smallholder farmers of Brassicas are incurring huge economic losses of horticultural crops due to Xanthomonas campestris pv. campestris and control of the disease progression has proved quite ineffective to contain by relying solely on synthetic pesticides [6]. Extensive and intensive chemical control can lead to pathogenic resistance which reduces chemical effectiveness especially when applied after symptom appearance in the crop [15]. The main objective of this study was to determine whether Moringa bark, seed and leaf extracts could actually suppress disease progression in field grown rape and also determine the optimum concentration level at which Moringa bark, leaf or seed extract can effectively suppress Xanthomonas campestris pv. campestris growth in field grown rape. Effect of Moringa extracts on rape growth was also assessed aimed at validating literature which states Moringa enhances crop growth.

\section{Materials and Methods}

\subsection{Site Description}

The field experiment was carried out in 
Dzivarasekwa 2, Harare, Zimbabwe during the 2015-2016 seasons. Dzivarasekwa is located at latitude $17^{\circ} 43^{\prime} \mathrm{S}$ and longitude $30^{\circ} 17^{\prime} \mathrm{E}$ with an altitude of 1,356 $\mathrm{m}$ above sea level.

\subsection{Experimental Design}

The experiment was laid out in a Split-Plot, $3 \times 3$ factorial with 4 replicates. Factor A was the Moringa extract at 3 levels (leaf, bark and seed). Factor B was the 3 concentrations at 3 levels (60\%, 100\% and 140\%). The main plots were the extract types and the sub-plots were the extracts concentrations. Each replicate had 3 plants.

\subsection{Experimental Details}

Diseased leaves where collected and examined and the pathogen was isolated in the pathology laboratory. The Sandwich ELISA (Enzyme Linked Immunosorbent Assay) was used as a specific method of identifying the disease causal pathogens. All the reagents were from the University of Zimbabwe pathology laboratory. The sandwich ELISA with 96 wells micro tighter plate was used. Antibodies specific to Xanthomonas campestris obtained from the pathology laboratory was loaded, putting $100 \mathrm{~mL}$ into each of the wells for the three areas separately. These were incubated at $25{ }^{\circ} \mathrm{C}$ overnight so that they stick to the plate. The plate was washed three times using PSB (phosphate buffer solution). The wells were flooded, tipped over the sink and banged over a tissue paper to dry the plate. The target sample (antigen) of the diseased plants of the three areas was added 100 micro liters into each well. Antigen preparation was done by collection of infected samples from Dzivarasekwa, which were weighed and $1 \mathrm{~g}$ of the tissue for each specific sample area was ground, $10 \mathrm{~mL}$ of PBS was added. The samples were then filtered using a double cheese cloth. The samples were incubated at $25{ }^{\circ} \mathrm{C}$ overnight.

To culture the bacteria, the diseased leaves were disinfected with $1 \%$ jik to eliminate saprophytes that might contaminate the culture. A direct plating method on NA (Nutrient Agar) was done and the bacterium was incubated at $25{ }^{\circ} \mathrm{C}$ overnight. To prepare the bacterial suspension, the inoculating loop was used to scrape loop-full of bacteria and was suspended in 100 $\mathrm{mL}$ sterile distilled water in a beaker. A steering rod was used to mix the bacteria with the sterile water and it was ready for use.

The Moringa seed leaf and bark powders were obtained from Mutoko District, Zimbabwe. The aqueous extracts were prepared by suspending $60 \mathrm{~g}$, $100 \mathrm{~g}$ and $140 \mathrm{~g}$ powders of each of the extracts separately in $100 \mathrm{~mL}$ of sterile water. The samples were shaken and stirred continuously for 30 minutes and allowed to sediment at room temperature for 24 hours, after which they were strained with a muslin cloth. The aqueous extracts were the $60 \%, 100 \%$ and $140 \%$ concentration levels.

The land was ploughed using a tractor and the beds were made using hand hoes. Two blocks A and B each with 9 beds were prepared. The beds measured $2 \mathrm{~m} \times$ $2 \mathrm{~m}$. The beds were pre-watered to field capacity. Fertilizer compound S (8:10:10) was applied at a rate of $800 \mathrm{~kg} / \mathrm{Ha}$ (actual applied was $5 \mathrm{~g}$ per planting station). The rape seeds were sown at a rate of $3 \mathrm{~kg} / \mathrm{Ha}$ (actual sown 5 seeds per planting station). The seedlings were then thinned to leave one plant per station at four weeks after planting.

To inoculate with Xcc bacteria, the fully expanded top two leaves of each plant were pricked and a third of a section of the leaf was cut using sterilized, stainless steel scissors, to improve the penetration of bacteria. The freshly prepared inoculum suspension from the cultured bacteria was sprayed onto each individual plant using 1 liter hand sprayers to run off point. The inoculation was done at 5 weeks after planting.

The three extracts at different concentration of $60 \%$, $100 \%$ and $140 \%$ were applied exogenously on Brassica napus on a weekly basis from 6 weeks after planting. Data collection started 6 weeks after planting and was done on a weekly base. Totally defoliated 
plants were counted to evaluate the suppressive efficacy of the different Moringa extracts.

\subsection{Data Analysis}

The data were analyzed using Excel and GenStat 14th Edition. The means were separated using LSD (Least Significant Difference) at 5\% level.

\section{Results}

Moringa seed extract was the most effective in suppressing or controlling black rot disease caused by the Xcc pathogen compared to leaf and bark extract (Figs. 1a and 1b). Plants A and B were sprayed at 60\% concentration level with seed extracts and leaf extracts respectively. The pictures clearly reveal the devastating effect of the pathogen and also the extent to which the different Moringa extracts can suppress the black rot disease progression caused by Xanthomonus campestris pv. campestris.

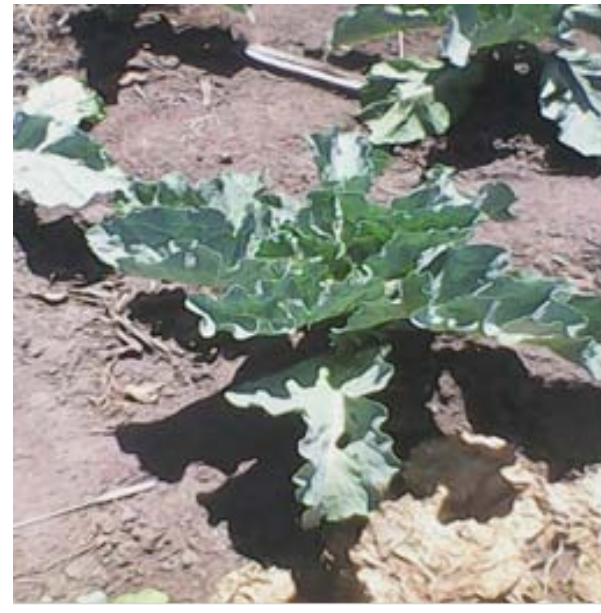

(a)
The interaction between Moringa bark, leaf and seed extract concentrations and Xanthomonas campenstris pv. campenstris progression was studied to determine the efficacy of the extracts in controlling the pathogen that cause leaf defoliations in Brassica napus. The results showed significant difference in the performance of the extracts observed in weeks 6 and 8 after crop emergence $(p<0.05)$. In contrast, no significant differences were observed between the three Moringa extracts and the pathogen between weeks 2, 3, 4, 5 and 7 after crop emergence ( $p<0.05$ ). The seed extract recorded the least leaf defoliation and leaf extracts recorded the most leaf defoliation (Table 1).

It is also quite clear that there was a significant difference $(p<0.05)$ amongst the three extracts in Week 6 (Table 1). The seed extract had lower mean leaf defoliation of 1.678, followed by bark and leaf extracts with 2.067 and 2.301 mean leaf defoliation

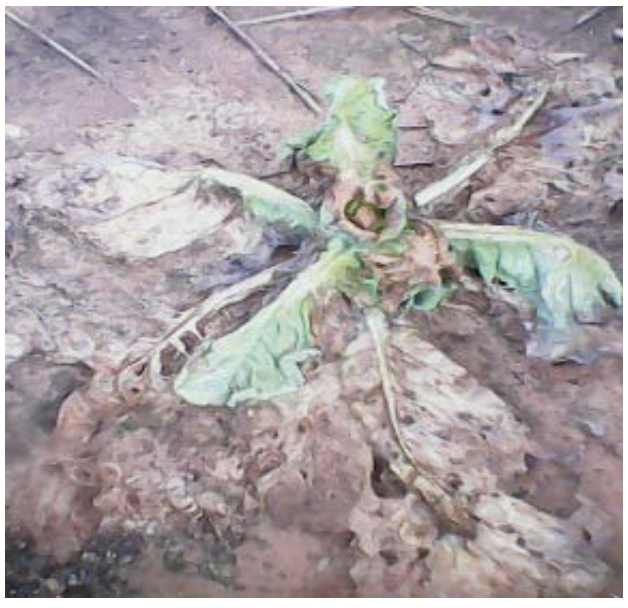

(b)

Fig. 1 (a) B. napus with $60 \%$ seed extract and (b) B. napus sprayed with $60 \%$ leaf extracts.

Table 1 Effects of Moringa leaf, bark and seed extracts on rape leaf defoliation from 2 to 8 weeks after crop emergence.

\begin{tabular}{llllllll}
\hline Treatment & 2WAE & 3WAE & 4WAE & 5WAE & 6WAE & 7WAE & 8 WAE \\
\hline Bark extract & 1.192 & 1.365 & 1.618 & 1.719 & $2.067^{\mathrm{a}}$ & 2.510 & $2.576^{\mathrm{b}}$ \\
Leaf extract & 1.025 & 1.112 & 1.451 & 1.708 & $2.301^{\mathrm{c}}$ & 2.725 & $2.964^{\mathrm{b}}$ \\
Seed extract & 0.880 & 1.025 & 1.171 & 1.403 & $1.678^{\mathrm{b}}$ & 1.858 & $1.859^{\mathrm{a}}$ \\
$p$ Value & 0.294 & 0.130 & 0.208 & 0.241 & 0.013 & 0.053 & 0.036 \\
LSD 5\% & 0.6144 & 0.4148 & 0.7052 & 0.5699 & 0.2229 & 0.6519 & 0.6595 \\
CV \% & 13.8 & 8.3 & 11.6 & 8.2 & 2.6 & 6.4 & 6.2 \\
\hline
\end{tabular}

Means not sharing a common letter in a column differ significantly at $p<0.05$ and means without letters in a column are not significantly different.

Key: WAE $=$ Weeks after emergence. 
respectively (Fig. 2). The results were consistent during 8 weeks after emergence, the seed extracts had lower mean leaf defoliation of 1.859 followed by bark and leaf extracts with 2.576 and 2.964 mean leaf defoliations respectively (Fig. 2). However, there was no significant difference $(p>0.05)$ between bark extracts and leaf extracts in Week 8 (Fig. 3)

There was significant difference amongst the three extracts at week six after crop emergence $(p<0.05)$. Higher activity was observed with the seed extract which had lower mean leaf defoliation (1.678) followed by bark (2.067) and lastly leaf extracts (2.301) respectively (Fig. 2).

At Week 8 the seed extract exhibited the lowest mean leaf defoliation compared to the other two extracts (1.585), whilst the bark and leaf extracts were not statistically different from each other, exhibiting means of 2.576 and 2.964 respectively.

There was strong evidence that showed that Moringa seed extract levels were significant $(p<0.05)$ in enhancing stem diameter only, with $60 \%$ seed extract having the highest mean stem diameter $(1.529 \mathrm{~cm})$ compared to $100 \%$ and $140 \%$ levels which had 1.323 $\mathrm{cm}$ and $1.404 \mathrm{~cm}$ mean diameters respectively (Table 2). However it was also apparent that $100 \%$ and $140 \%$ seed extract levels were not significantly different from each other (Fig. 4). Surprisingly the bark and leaf extracts were not significant on all tested growth parameters.

\section{Discussion}

The three extracts (leaf, bark and seed) of Moringa showed varying degrees in controlling activities against the Xanthomonas campestris pv. campestris in their performance. The result of the study indicated that the seed extract had a higher antibacterial activity against Xanthomonas campestris pv. campestris as compared to the bark and leaf extracts. It was not clear if the different levels of activity amongst the extracts were due to the type of active ingredient that was extracted since each plant part has different percentages of the bioactive compounds such as terpenins, tanins, saponins, benzyl isothiocyanate etc. [16]. The positive effects of the Moringa seed extracts

\section{Week 6}

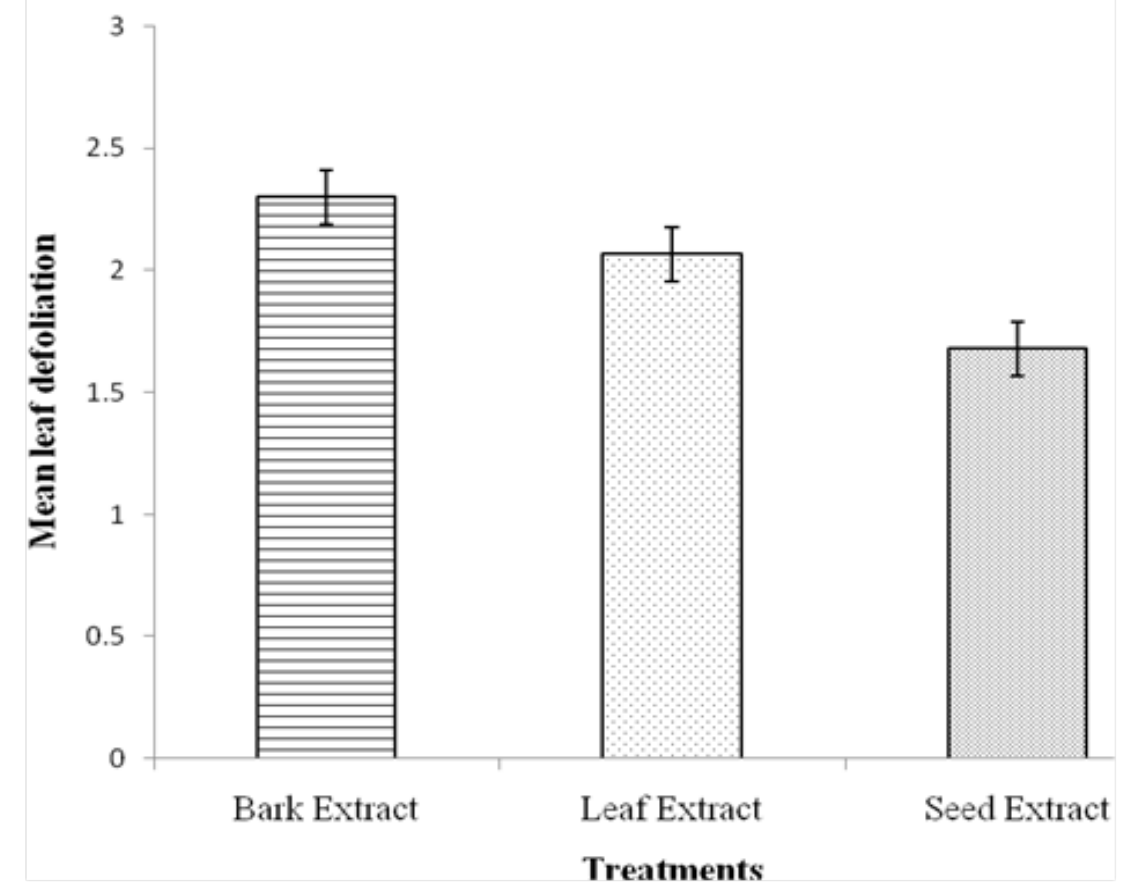

Fig. 2 Effects of Moringa Extracts on rape leaf defoliation at 6 weeks after emergence (Bars at LSD 0.05). $p=0.013$. 


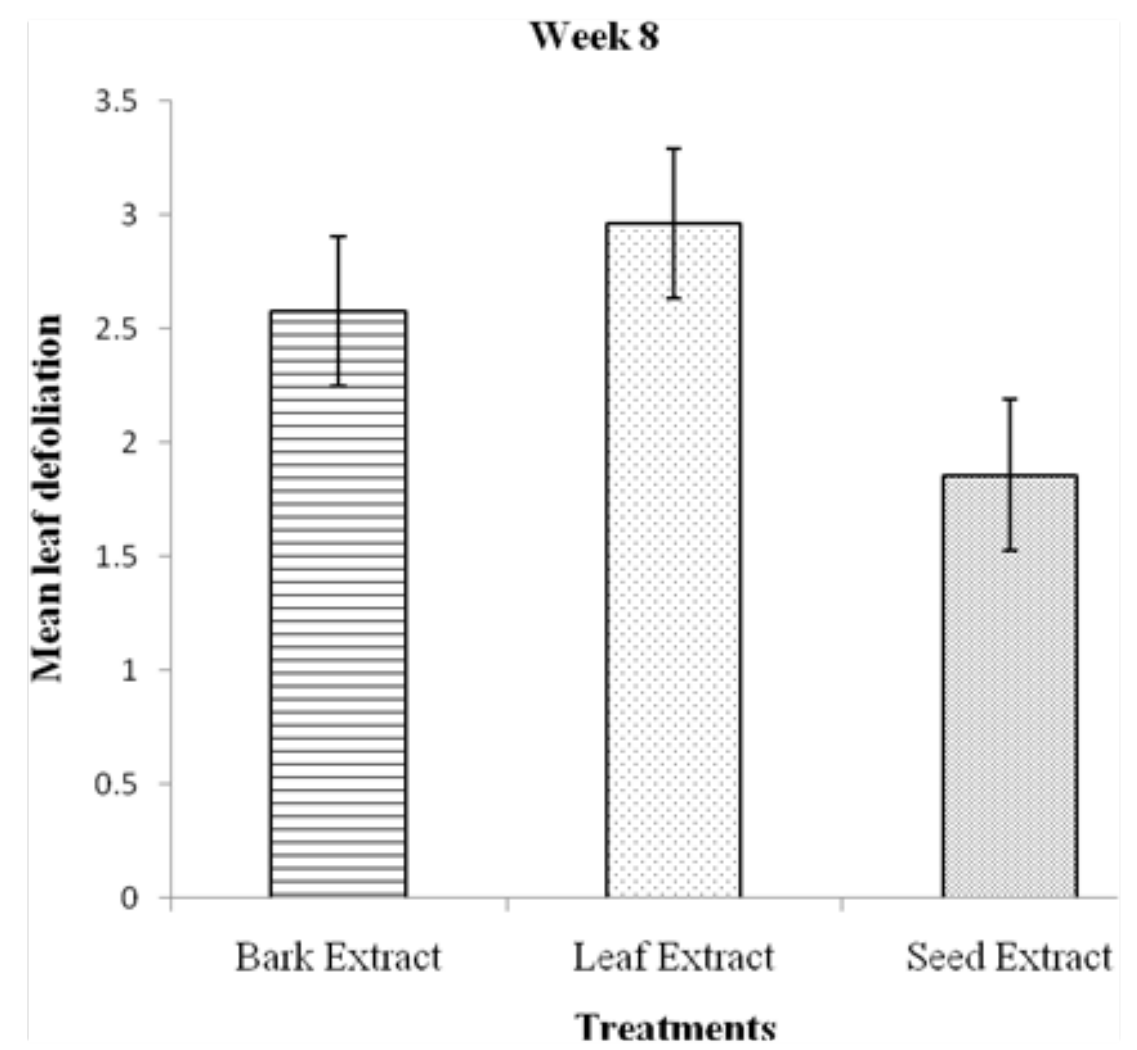

Fig. 3 Effects of Moringa extracts on rape leaf defoliation at 8 weeks after emergence (Bars at LSD 0.05). $p=0.036$.

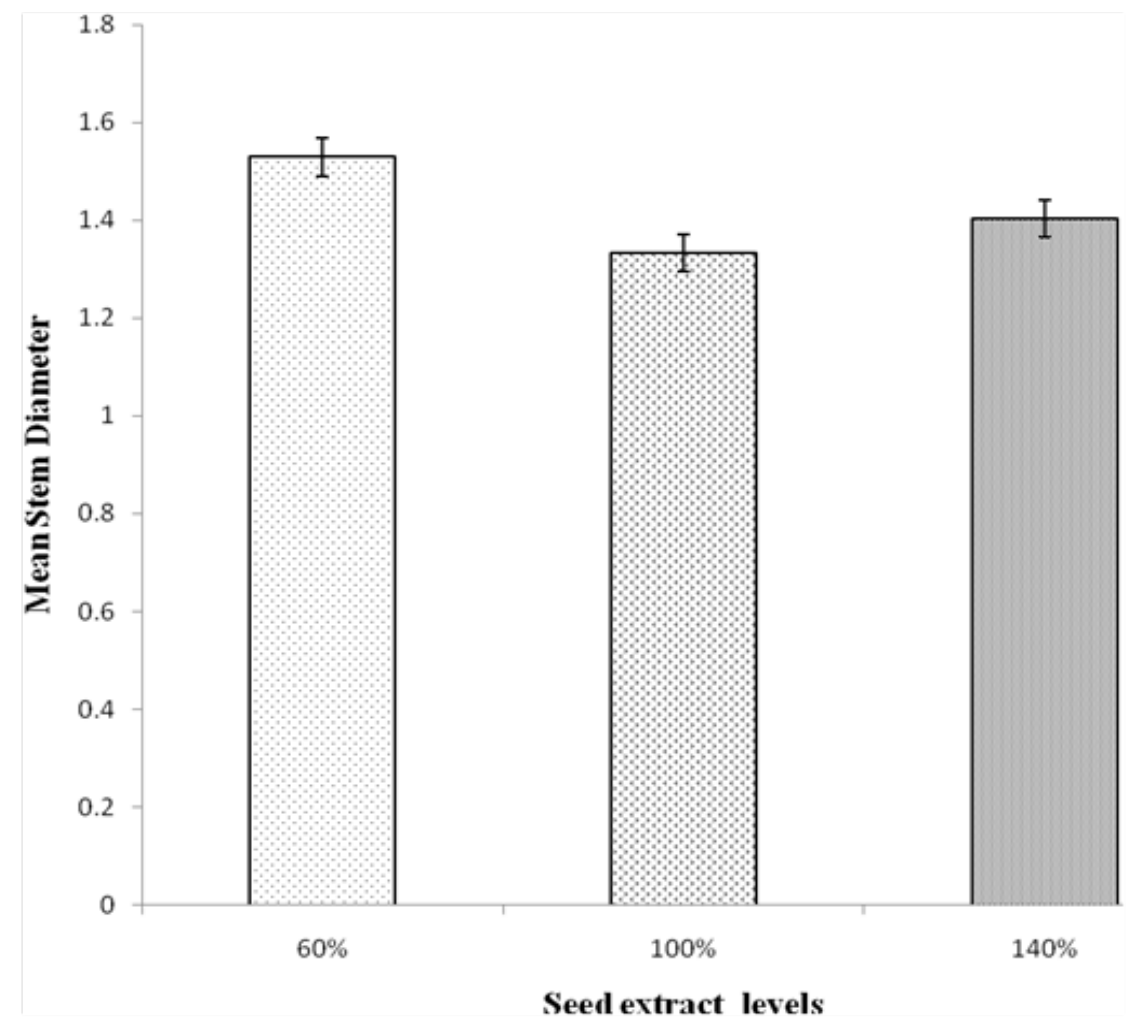

Fig. 4 Effects of exogenous seed extract application on rape stem diameter (Bars at LSD 0.05). $p=0.016$. 
can be attributed to the fact that the seed extract was reported to have a double effect in suppressing bacterial growth compared to other extracts due to the presence of Moringa oil, which enhances the activity of the benzyl isothiocyanate [17]. According to Patel et al. [14], Moringa seed contains a recombinant protein effective against Gram negative and Gram positive bacterial cells and directly inhibits the growth of microorganisms. This strong antibacterial activity exhibited by Moringa seed extract against Xcc pathogen, is further explained by Singh et al. [2] who state that Moringa leaf and seed compounds have an anti-quorum sensing ability which improves their action as bacteriocides. However, based on the findings in the current study, the Moringa seed appears to contain a higher level of these anti-quorum sensing abilities compared to the leaf as it performed with more efficacy against the test pathogen compared to leaf extracts.

The results obtained for the bark and leaf extracts however contradict those obtained by Shih et al. [18] who studied the composition of the leaf, stalks and roots of the Moringa tree and stated that the leaf contained the highest amount of phenolic compounds and antioxidant activity. Phenolic compounds are part of the secondary metabolites which are involved in plant defense against pathogens [16]. Studies by Lurling et al. [13] revealed the total wipeout of cynabacterium Microcystis aeruginosa, which causes water contamination and foul smells in drinking water, by using crushed Moringa seed extract. These same studies revealed increased anti-cyanobacterial activity of the Moringa seed as concentration was increased.

The results of the current study surprisingly indicated that there was no significant difference in the concentration levels (60\%, 100\% and 140\%) of the three extracts against Xanthomonas campestris pv. campestris. This, however, contradicted with findings by Hussain et al. [11] who stated that increasing concentrations of Moringa bark and leaf extracts (10\%-80\%) increased the diameter of the zone of inhibition on Staphylococcus aureus and Escherichia coli pathogen in invitro conditions. The current study was a field experiment, and presumably, environmental factors such as temperature, drought stress and rain are bound to have influenced the efficacy of the Moringa leaf extracts. Efficacy was reduced by rain wash and high ambient temperatures above $25{ }^{\circ} \mathrm{C}$ that denatured the extracts reducing their efficacy. It has been reported by Wahid and Jamil [19], that high ambient temperature results in extracts enzyme inactivity reducing their efficacy. The GC/MS analysis carried out on the study Moringa plant extracts, revealed the presence of Tanins, Flavnoids and Polyphenols which are said to be antibacterial in nature [20], hence the ability of Moringa extracts to control black rot caused by Xcc. Furthermore, the presence of $4(\alpha$-L-rhamsyloxy) benzyl-isiothocyanate in the Moringa extracts used in the study, inferred the antibacterial action against $X c c$, as this is the main compound associated with antimicrobial activity in Moringa plant [17]. Sreelatha and Padma [21], further attribute the ability of Moringa to suppress pathogen growth to the high level of antioxidants, which causes an antioxidative burst within plant cells which triggers the plant defense mechanisms against scavenging radicals and pathogenic invasions. The presence of Moringa oil within the Moringa seed extract, infers the presence of saponins (oily glycosides) which are normally used in cleaning agents and hydrolysis by enzymes or acids, which results in production of a sugar and a sapogenin which is either a triterpene or a steroid [22]. These compounds have detergent like properties and they disrupt the cell membranes of invading pathogens [16]. The high levels of phenolic compounds present in Moringa extracts used for this study, might have enhanced efficacy against $X c c$, as these phenolic compounds contain phytoalexins, which are isoflavanoids with antibiotic and antifungal properties. These properties are produced in response to pathogen attack.

Only the $60 \%$ seed extract level showed plant 
growth enhancing properties which therefore, can be exploited and used as natural plant growth enhancers. Moringa seed extracts have been reported to have abundant zeatin, potassium and calcium [10] which are capable of enhancing crop growth.

The Moringa leaf and bark extracts levels had no significance difference on all the tested growth parameters. However, this contradicted with research findings done by Mathur [23] who observed that Moringa leaf extracts could enhance the growth of tomatoes (Solanum lycopersicum), peanut (Arachis hypogaea), corn (Zea mays) and wheat (Triticum aestivum) during the early stages of growth by $20 \%$ to $30 \%$. Further studies by Phiri [24] indicated that Moringa extract enhances germination and establishment of cereal crops. The factors which might have contributed to the differences were that firstly, the two experiments were not independent trials so they affected each other. The pathogen defoliated some plants and there was total loss of some of the treatments. This resulted in failure of obtaining measurements for the missing plants hence analysis was made for only one data set recording were there was a full complement of the data (Week 6 after crop emergence). The other factor which might have influenced the observations that leaf harvests were not affected significantly by the Moringa extracts, was the fact that farmers disregarded the once weekly harvesting schedules provided to them when researchers were supposed to harvest and take recordings, but instead, the farmers harvested for household consumption whenever they needed the vegetables. Such harvests done by the farmers for home consumption were not recorded. This indicates the need for a separate study aimed at validating effect of Moringa extracts on field grown crops on growth, yield and quality. Such a study would add on to the wealth of information which is critical for organic farmers.

\section{Conclusions}

The results of this study validated without a shred of doubt that Moringa extracts possess antibacterial properties in significant enough quantities to effectively control black rot disease in rape (Brassica napus) grown under uncontrolled, natural open field conditions. There remains however, the need for further studies to assess its efficacy against other crops under field conditions and also, to identify the mechanisms and crop plant processes triggered to affect this antibacterial effect. Plants react in various ways to pathogenic attack and it would be interesting to identify the molecular responses of crop plants to the presence of Moringa bioactive compounds as it combats the pathogenic attack at cellular level.

Understanding the mechanisms involved and the trigger points, would aid in identifying the most optimum stage of crop growth at which to apply the biological control agents and identify which is the most ideal way of application. There is also need to track which of the bioactive phytochemicals present in Moringa are found in high levels in the study crops in order to identify which active ingredient would be responsible for each observed antibacterial activity within the plant.

\section{Acknowledgments}

The researchers would like to acknowledge assistance received from the following: the CAF (Central Analytical Facilities), Stellenbosch University in the Mass Spectrometry Unit, for phytochemical analysis of the Zimbabwean Moringa accessions used in this study; Dr. David Icishahayo (post-humously) for analytical input; Crop Science department pathology and field laboratory staff; Pedstock Nurseries for raising the rape seedlings; the University of Zimbabwe Research Board for funding the bulk of this research. And last but not least, the lead farmers from Dzikwa Trust for availing their land and their involvement in this research.

\section{References}

[1] Berger, R. D. 1977. "Application of Epidemiological Principles to Achieve Plant Disease Control.” Annual 


\section{in Field Grown Rape (Brassica napus)}

Review of Phytopathology 15 (1): 165-81.

[2] Singh, D., Rathaur, P. S., and J. G. Vicente. 2016. "Characterization, Genetic Diversity and Distribution of Xanthomonas Campestris Pv. campestris Races Causing Black Rot Disease in Cruciferous Crops of India.” Plant Pathology, July. doi:10.1111/ppa.12508.

[3] Berthier, Y., Valerie, V., Jean-Luc, G., Chevrier, D., Jean-Baptiste, D., Decoux, G. U. Y., and Monique, L. 1993. "Characterization of Xanthomonas Campestris Pathovars by rRNA Gene Restriction Patterns” Applied and Environmental Microbiology 59 (3): 851-9.

[4] Seebold, K., Bachi, P., and Beale, J. 2008. "Black Rot of Crucifers.” Plant Pathology Fact Sheet.

[5] Vicente, J. G., and Holub, E. B. 2013. "Xanthomonas campestris $p v$. campestris (Cause of Black Rot of Crucifers) in the Genomic Era Is Still a Worldwide Threat to Brassica Crops.” Molecular Plant Pathology 14 (1): 2-18.

[6] Nyamupingidza, T. N., and Machakaire, V. 2003. "Virus Diseases of Important Vegetables in Zimbabwe.” In Plant Virology in Sub-Saharan Africa: Proceedings of a Conference Organized by IITA, 4-8 June 2001, International Institute of Tropical Agriculture, Ibadan, Nigeria, 397. IITA.

[7] Zhao, X., Chambers I. V. E., Matta, Z., Loughin, T. M., and Carey, E. E. 2007. "Consumer Sensory Analysis of Organically and Conventionally Grown Vegetables.” Journal of Food Science 72 (2): 1-19.

[8] Elwell, H., and Maas, A. 2006. "Plants Can Solve Farmers' Problems." Network.

[9] Al-askar, A. A, and Rashad, Y. M. 2010. "Efficacy of Some Plant Extracts against Rhizoctonia solani on Pea." Journal of Plant Protection Research 50 (3): 239-43. doi:10.2478/v10045-010-0042-0.

[10] Foidl, N., Makkar, H. P. S., and Becker, K. 2001. "The Potential of Moringa oleifera for Agricultural and Industrial Uses." The Miracle Tree: The Multiple Attributes of Moringa, 45-76.

[11] Hussain, S., Malik, F., and Mahmood, S. 2014. “An Exposition of Medicinal Preponderance of Moringa Oleifera (Lank.).” Pakistan Journal of Pharmaceutical Sciences 27 (2).

[12] Lang, U. M., Roloff, A., Schütt, P., Stimm, P., and Weisgerber, H. 2007. Enzyklopädie der Holzgewächse: Handbuch und Atlas der Dendrologie /begründet von Peter Schütt. Andreas Roloff; Horst Weisgerber; Ulla M. Lang; Bernd Stimm. Weinheim: Wiley-VCH.

[13] Lürling, M., and Beekman, W. 2010. "Anti-Cyanobacterial Activity of Moringa oleifera Seeds." Journal of Applied Phycology

22

(4):

503-10. doi:10.1007/s10811-009-9485-y.

[14] Patel, N., Patel, P., Patel, D., Desai, S., and Meshram, D. 2016. "Phytochemical Analysis and Antibacterial Activity of Moringa oleifera." http://www.academia.edu/download/33635969/4._Medici ne_-Phytochemical_Analysis_-_Nivedita_Patel.pdf.

[15] Ogle, H. 2016. Disease Management: Chemicals. Accessed September 11. http://www.appsnet.org/Publications/Brown_Ogle/24\%20 Control-Chemicals\%20(HJO).pdf.

[16] Freeman, B. C., and Beattie, G. A. 2008. "Overview of Plant Defenses against Pathogens and Herbivores.” The Plant Health Instructor. doi:10.1094/PHI-I-2008-0226-01.

[17] Rasika, J. 2013. “Antimicrobial Activity of Moringa oleifera and Its Synergism with Cleome Viscosa.” Int. J. Life Sciences 1 (3): 182-9.

[18] Shih, M. C. Chang, C. M., Kang, S. M., and Tsai. M. L. 2011. "Effect of Different Parts (Leaf, Stem and Stalk) and Seasons (Summer and Winter) on the Chemical Compositions and Antioxidant Activity of Moringa Oleifera.” International Journal of Molecular Sciences 12 (12): 6077-88. doi:10.3390/ijms12096077.

[19] Wahid, A., and Jamil, A. 2009. "Inducing Salt Tolerance in Canola (Brassica napus L.) by Exogenous Application of Glycinebetaine and Proline: Response at the Initial Growth Stages.” Pak. J. Bot 41 (3): 1311-9.

[20] Makkar, H. P. S., Francis, G., and Becker, K. 2007. "Bioactivity of Phytochemicals in Some Lesser-Known Plants and Their Effects and Potential Applications in Livestock and Aquaculture Production Systems.” Animal 1 (09). doi:10.1017/S1751731107000298.

[21] Sreelatha, S., and Padma, P. R. 2009. “Antioxidant Activity and Total Phenolic Content of Moringa oleifera Leaves in Two Stages of Maturity." Plant Foods for Human Nutrition $64 \quad$ (4): $\quad 303-11$. doi:10.1007/s11130-009-0141-0.

[22] Azubuogu, C. U. 2012. "Phytochemical Analysis on Moringa oleifera and Azadrichta indica Leaves.” Nigeria: Department of Chemical Engineering Faculty of Engineering Caritas University Enugu Nigeria.

[23] Mathur, B. 2006. "Moringa for Cattle Fodder and Plant Growth.” Trees for Life Publication. http://www.tfljournal.org/files/Moringa\%20for\%20fodde r\%20\%26\%20spray\%20(screen).pdf.

[24] Phiri, C. 2010. "Influence of Moringa oleifera Leaf Extracts on Germination and Early Seedling Development of Major Cereals. Agriculture and Biology Journal of $\begin{array}{llll}\text { North } & \text { America } & 1 & \text { (5): }\end{array}$ doi:10.5251/abjna.2010.1.5.774.777. 